\title{
Surface Modification of Commercial Activated Carbon (CAG) for the Adsorption of Benzene and Toluene
}

\author{
Anna Sylmara da Costa Lopes ${ }^{1}$, Samira Maria Leão de Carvalho1, \\ Davi do Socorro Barros Brasil1 ${ }^{1}$, Rosivaldo de Alcântara Mendes², Marcelo Oliveira Lima² \\ ${ }^{1}$ Universidade Federal do Pará, Belém, Brasil \\ ${ }^{2}$ Instituto Evandro Chagas, Ananindeua, Brasil \\ Email: annalopes.ta.qi@hotmail.com
}

Received 11 February 2015; accepted 5 May 2015; published 8 May 2015

Copyright @ 2015 by authors and Scientific Research Publishing Inc.

This work is licensed under the Creative Commons Attribution International License (CC BY). http://creativecommons.org/licenses/by/4.0/

c) (i) Open Access

\begin{abstract}
In this work, we determined the surface characteristics of natural (CA-1) and $\mathrm{HNO}_{3}$ treated (CA-2) CAG. Equilibrium, kinetics and breakthrough for adsorption of benzene and toluene by CA-1 and CA-2 were studied. Concentrations of benzene and toluene $(\mathrm{mg} / \mathrm{L})$ were determined by gas chromatography with headspace extraction. The data of adsorption kinetic and equilibrium were best fitted by pseudo-second order model and Langmuir isotherm, respectively. The best results of benzene and toluene adsorption from fixed bed were obtained at volumetric flow rate $\left(Q_{1}=70\right.$ $\mathrm{mL} / \mathrm{min}$ ) using adsorbent CA-2. The study of inferential statistics revealed that CA-1 and CA-2 adsorbents are statistically different at a $5 \%$ significance level.
\end{abstract}

Keywords

Adsorption, Activated Carbon, Surface Modification, Benzene, Toluene

\section{Introduction}

In recent years, with increasing population and industrial activity, intensified concerns regarding water quality, among these groundwater has received special attention. Contamination of water and soil by volatile organic compounds (VOCs), as a result of accidents or spills (fuel) and wastewater industrial today poses serious problems to public health [1]. Volatile organic compounds such as benzene and toluene are found frequently in the wastewater from paint industries, adhesives, plastics, petrochemicals, among others [2]. Benzene and toluene are flammable, toxic and carcinogenic substances, their presence in aqueous environments have a negative impact 
on water quality and thus endanger the welfare and public health [3]-[5].

Activated carbon (CA) has been used as adsorbent for the removal of a wide variety of organic and inorganic pollutants from aqueous media [6]. This adsorbent is widely used in the treatment of waste water due to their high surface area between $500-1500 \mathrm{~m}^{2} / \mathrm{g}$, well-developed internal structure of micropores, as well as a large variety of surface functional groups [7]. Exceptional adsorption of organic compounds by activated carbon is attributed to their hydrophobicity and ability to adsorb molecules with molecular weight between $45-130 \mathrm{~g} / \mathrm{g}$ mol [8]. CA adsorption has been cited by the North American Environmental Protection Agency (USEPA) as one of the best available technologies in environmental control [9].

The liquid phase adsorption is generally a more complex phenomenon than the adsorption of gas phase. The liquid phase adsorption is influenced by various factors such as solubility of the adsorbate, solution $\mathrm{pH}$, temperature and chemistry of the adsorbent surface [10]. The adsorption of organic compounds in aqueous phase by CA mechanism involves two main types of interactions: electrostatic and dispersive [11].

Although the performance of activated carbon as adsorbent for a wide variety of organic compounds is known [12], numerous studies are developed to study surface modifications of CA's, which could help to improve these materials, such as specific adsorbents of organic and inorganic contaminants present in wastewater [13]-[15].

The present study reports the influence of surface modification of $\mathrm{HNO}_{3}$ treated CAG for adsorption of benzene and toluene from aqueous solutions, and use of the inferential statistical analysis for the treatment of experimental adsorption data. The adsorption of benzene and toluene by CA can be a viable alternative for the removal of these compounds from aqueous systems, thus minimizing contamination. Since the aquifers are water supply sources for human consumer.

\section{Materials and Methods}

\subsection{Adsorbents}

Commercial granular activated carbon (GAC) of Synth ${ }^{\circledR}$ mark, particle size: 1 - 2 mm was used as an adsorbent (where was GAC source from). The adsorbent was washed and boiled for three hours in deionized water. It was subsequently dried in an oven $\left(105^{\circ} \mathrm{C}\right)$ for $24 \mathrm{~h}$ to make sample (CA-1).

Adsorbent CA-2 was obtained from CA-1 by treated with $6 \mathrm{M} \mathrm{HNO}_{3}$, according to the procedure described by Elhendawy [16]. Briefly $100 \mathrm{~mL}$ of $6 \mathrm{MHNO}_{3}$ were used to treat/10g CA-1 under reflux at $100^{\circ} \mathrm{C}$ for $2 \mathrm{~h}$. The adsorbent was subsequently washed with deionized water to neutral $\mathrm{pH}$ and dried at $105^{\circ} \mathrm{C}$ for $24 \mathrm{~h}$ to make sample (CA-2).

\subsection{Characterization of the Adsorbent}

\subsubsection{Specific Surface Area and Total Pore Volume $\left(V_{p}\right)$}

The values of specific surface area and total pore volume of the adsorbents were determined from $\mathrm{N}_{2}$ adsorption isotherms at $77 \mathrm{~K}$, using a porosimeter MICROMERITICS TRISTAR II.

\subsubsection{Determination of $\mathrm{pH}$}

The $\mathrm{pH}$ of activated carbon was determined according to previously reported standard method ASTM D383805 [17].

\subsubsection{Characterization of the Adsorbent Surface by FTIR}

Analyses were performed on spectrophotometer Fourier transform infrared (FTIR) Thermo Scientific Nicolet (IS 10 model) [18].

\subsubsection{Characterization of Functional Groups on the Surface of the Adsorbent}

The characterization of the surface functional groups of (CAG) was performed according to the Boehm methodology [19] [20]. In the determination of acid groups $5.0 \mathrm{~g}$ of the adsorbent were suspended in $50 \mathrm{ml}$ of $0.1 \mathrm{M}$ standard solutions (sodium hydroxide, potassium bicarbonate, $\mathrm{KHCO}_{3}$ and sodium carbonate, $\mathrm{Na}_{2} \mathrm{CO}_{3}$ ). The vials with the adsorbent suspensions were closed and shaken in a thermostatic bath $\left(27^{\circ} \mathrm{C}\right)$ at $140 \mathrm{rpm}$ for $24 \mathrm{~h}$. The suspensions were filtered $(0.45 \mu \mathrm{m}$ Millipore) and titrated with a solution of hydrochloric acid $\mathrm{HCl}(0.1 \mathrm{M})$.

In the determination of basic groups using $2.0 \mathrm{~g}$ of CAG were suspended in $20 \mathrm{ml}$ of $0.1 \mathrm{M}$-hydrochloric acid, 
under same experimental conditions as described for the determination of acid groups. After equilibration, the suspensions were filtered $(0.45 \mu \mathrm{m}$ Millipore) and a $10 \mathrm{ml}$ aliquot was titrated under continuous stirring (magnetic stirrer) against $0.1 \mathrm{M}$. sodium hydroxide. The identified functional groups CAG were calculated as mmol/g (MAS).

\subsection{Tests for Adsorption of Benzene and Toluene}

\subsubsection{Solutions of Organic Compounds Used for Adsorption}

Organic solutions (60 mg/L) were prepared from benzene (99.5\% purity) and toluene (99.8\% purity) according to the studies done by $\mathrm{Lu}, \mathrm{Su}$ and $\mathrm{Hu}$ [21].

\subsubsection{Analytical Determination of Organic Compounds}

The extraction methodology used to analyze benzene and toluene in the water samples was automated headspace method which is based on 6040D Supelco/Sigma-Aldrich [22]. Determination of benzene and toluene in water samples was performed according to EPA 0010 method [23]. Aliquots $(15 \mathrm{ml})$ of the samples were placed in 20 $\mathrm{ml}$ vials and sealed with aluminum seals, and teflon septum. The analytes were quantified by a gas chromatograph (Varian, CP 3800) connected to a mass spectrometer (MS-320 CTC Analytics) with auto-sampled system and headspace and flame ionization detector (GC-FID). The chromatograms were obtained and processed by Varian Star Workstation software.

\subsubsection{Kinetics and Balance Adsorption of Benzene and Toluene}

Kinetic assays and adsorption equilibrium were performed in thermostatic bath $\left(25^{\circ} \mathrm{C}\right)$ at $140 \mathrm{rpm}$ for contact time of up to 25 minutes. In the assays used aqueous solutions, concentrations of up to $60 \mathrm{mg} / \mathrm{L}$. The adsorption kinetics tests were performed at 3, 5, 7, 9, 13, 15, 17, 20, 22 and 25 minutes. Each assay consisted of about $1.0 \mathrm{~g}$ of adsorbent for every $100 \mathrm{ml}$ organic solution placed in closed glass vials and immersed in a thermostatic bath. Kinetic mathematical model of pseudo-second order in the linear form was used to correlate the experimental data obtained using Equation (1).

The adsorption isotherms were obtained by suspending about $1.0 \mathrm{~g}$ adsorbent in $100 \mathrm{~mL}$ of different organic solution concentrations (1.0, 1.5, 3.0, 5.0, 10.0, 15.0, 20.0, 25.0, 30.0, 40.0, 50.0 and $60.0 \mathrm{mg} / \mathrm{L})$, contained in closed glass vials (mouth grinded) and immersed in thermostatic bath for 25 minutes. Equation (2) shows the mathematical model of Langmuir, which was used to correlate the experimental data. Equation (3) was used to calculate the amount of adsorbed benzene and toluene $\left(\mathrm{Q}_{\mathrm{e}} \mathrm{mg} / \mathrm{g}\right)$. The percent removal of compounds by adsorption was calculated according to Equation (4).

$$
\begin{aligned}
& \frac{t}{q_{t}}=\left(\frac{1}{k_{2} q_{e}}\right)+\left(\frac{1}{q_{e}}\right) t \\
& \frac{C_{e}}{q_{e}}=\left(\frac{1}{Q_{0} k_{L}}\right)+\left(\frac{1}{k_{L}}\right) C_{e} \\
& q_{e}=\frac{V\left(C_{i}-C_{e}\right)}{M} \\
& R(\%)=100\left(\frac{C_{i}-C_{e}}{C_{i}}\right)
\end{aligned}
$$

where: $q_{e}$ and $q_{t}$ is the amount of benzene or toluene adsorbed (mg/g) at equilibrium and at time $\mathrm{t}$ (min), respectively; $k_{2}$ is the rate constant pseudo second order (g/mg-min); $C_{i}$ and $C_{e}$ are benzene concentrations(mg/L) at initial and equilibrium respectively; $Q_{o}$, maximum adsorbed amount (mg/g); $k_{L}$ Langmuir constant (L/mg); $V$ is the volume of solution (L); $M$ is the mass the adsorbent (g) and $\mathrm{R}$ is the adsorption efficiency of benzene or toluene (\%).

\subsubsection{Tests for the Adsorption of Benzene and Toluene Fixed Bed}

A bird with the following dimensions was employed: a glass column of $40 \mathrm{~cm}$ in height; bed height (HL) of 24.2 
$\mathrm{cm}$, bed internal diameter (ID) of $2.5 \mathrm{~cm}$, adsorbent mass (m) of $63.0 \mathrm{~g}$. The conical base and the top of the column was filled with glass beads $(0.5 \mathrm{~mm}$ diameter). The following values for the volumetric feed flow rate of the column were used: $70 \mathrm{~mL} \cdot \mathrm{min}^{-1}(\mathrm{Q} 1)$ and $100 \mathrm{ml} \cdot \mathrm{min}^{-1}(\mathrm{Q} 2)$ in downward flow.

Both adsorbents (CA-1 and CA-2) were used separately in benzene and toluene and two values of volumetric flow rates (Q1 and Q2 respectively) were obtained. A total of eight runs were performed using $12 \mathrm{~L}$ of a 60 $\mathrm{mg} / \mathrm{L}$ organic solution per run and contact time of 172.5 minutes and 120 minutes were used respectively for the values of volumetric flow rate of Q1 and Q2 at ambient temperature $\left(25^{\circ} \mathrm{C}\right)$. During the adsorption process were collected 19 samples were collected from which were used to determined the residual concentrations of benzene and toluene by gas chromatography headspace extraction.

\subsubsection{Statistical Analysis}

The inferential statistics were used to predict the distribution of the experimental data by applying the Kolmogorov-Smirnov test (reference), which it defines whether the samples are parametric or nonparametric. This test will evaluate, at a significance level of 5\%, if there are significant differences between CA-1 and CA-2 adsorbents using the results from the studies of adsorption kinetics and equilibrium of benzene and toluene.

Student $t$ test (parametric samples) and Wilcoxon paired test (non-parametric samples) were applied.

\section{Results and Discussion}

\subsection{Characterization of the Adsorbent}

\subsubsection{Specific Surface Area (SBET) and pH}

Table 1 shows the results obtained for some of the physical properties of the adsorbents.

Adsorbent CA-1 showed basic $\mathrm{pH}$ of 8.9 whileacid treated CA-2 showed a $\mathrm{pH}$ value of 3.8. According to Villacanas et al [24], the basic character of activated carbon results from the contribution of two factors. One is related to surface groups, such as pyrone and chromene and the other is associated with the existence of regions rich in $\pi$ electrons of grafênicas layers, which act as Lewis base [25]. The activated carbons that have acidic surfaces are characterized by high oxygen contentcontaining functional groups such as carboxylic, phenolic and lactones.

The value of specific surface area is comparable to the values reported in the literature [26] (823.1 - 982.9 $\mathrm{m}^{2} / \mathrm{g}$ ). Generally, the adsorption capacity increases with increasing specific surface area due to the availability of sites for adsorption [27]. According to Mangun et al [28], the percentage of removal of BTEX in aqueous solution generally increases with increasing surface area.

It can be seen that the $\mathrm{V}_{\mathrm{P}}$ and SBET values are approximately the same for both adsorbents. In CA-2, the lowerin specific surface area is due to partial or complete blockage of oxygen in the complex pore wall [29] [30]. Similar results were reported [31] [32].

\subsubsection{Functional Groups on the Adsorbents Surface}

Table 2 shows the results obtained for the determination of surface groups using the Boehm method.

There is a higher proportion of acidic groups in adsorbent CA-2 compared to CA-1 sample. This can be attributed to the preferential reaction of nitric acid with the basic groups (pyrones and chromenes) forming acidic groups by opening the heterocycles [33]. Acidification of the surface gives the activated carbon a higher ion exchange capacity and amphoteric character due to introduction of various functional groups on the surface [34]. According to Daifullah and Girgis [35], the presence of carboxyl groups promotes increased adsorption capacity of activated carbon for BTEX.

\subsubsection{Characterization of the Adsorbent Surface by Infrared Fourier Transform}

Figure 1 shows the FTIR spectra of CA-1 and CA-2. The FTIR spectrum of the adsorbent CA-1showed bands

Table 1. Physical properties of adsorbents.

\begin{tabular}{cccc}
\hline Adsorbent & $\mathbf{S}_{\text {BET }}\left(\mathbf{m}^{2} / \mathbf{g}\right)$ & $\mathbf{V}_{\mathbf{P}}\left(\mathbf{c m}^{3} / \mathbf{g}\right)$ & $\mathbf{p H}$ \\
\hline CA-1 & 803.43 & 0.41 & 0.9 \\
CA-2 & 703.66 & 0.35 \\
\hline
\end{tabular}


Table 2. Acidic and basic functional groups on the surface of activated carbon.

\begin{tabular}{ccc}
\hline & \multicolumn{2}{c}{ Quantity (mmol/g) } \\
\cline { 2 - 3 } Functional groups & CA-1 & CA-2 \\
\hline Carboxylic (-COOH) & 0.15 & 1.07 \\
Phenolic (-AR-OH) & 0.95 & 1.24 \\
Lactones (-COOR) & 0.05 & 1.50 \\
Basic groups & 2.60 & 1.40 \\
\hline
\end{tabular}

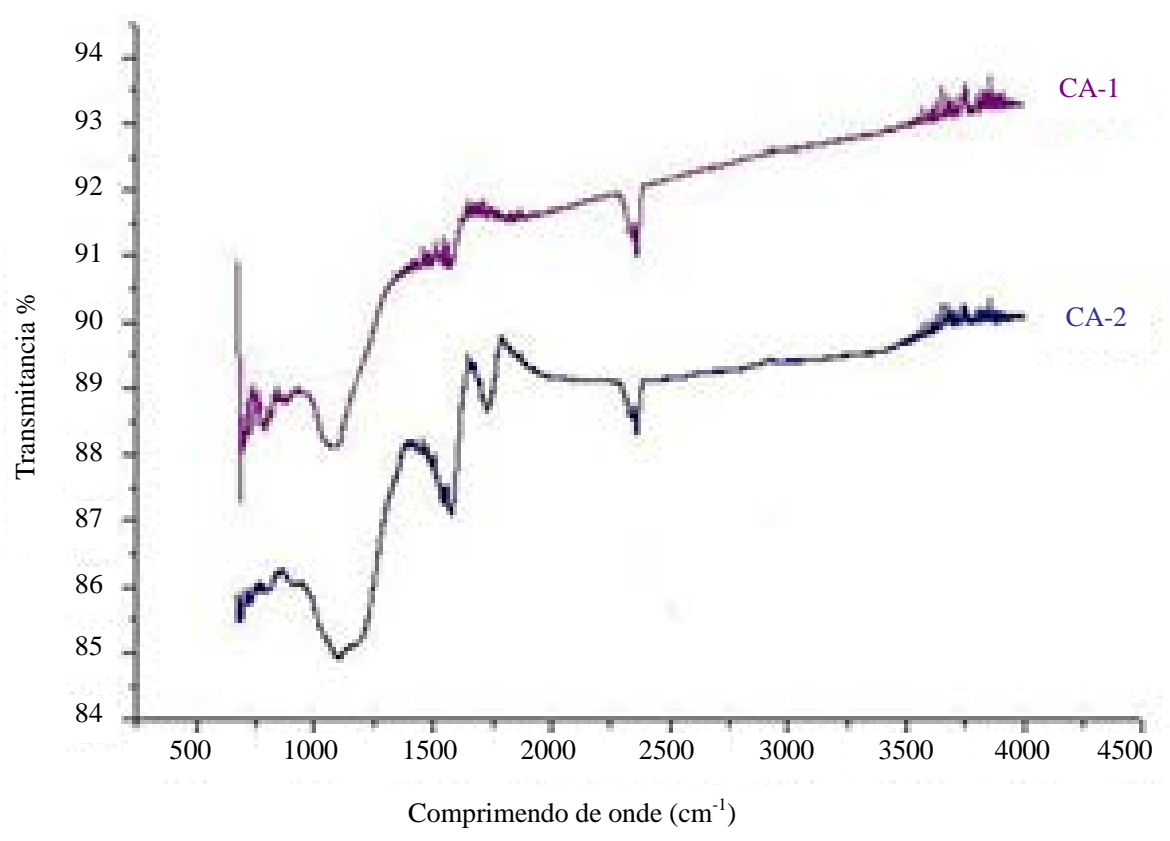

Figure 1. FTIR spectra of CA-1 and CA-2.

around $1100-1180 \mathrm{~cm}^{-1}, 1550-1600 \mathrm{~cm}^{-1}$ and $2300 \mathrm{~cm}^{-1}$, which are attributed to stretching and vibration of $\mathrm{CO}$ group, stretch of $\mathrm{C}=\mathrm{O}$ and presence of carboxylic groups and stretch of $\mathrm{CH}_{2}$ and $\mathrm{CH}_{3}$, respectively.

The peaks from 500 to $2000 \mathrm{~cm}^{-1}$ are assigned to carboxyl groups. The intense band at $1750 \mathrm{~cm}^{-1}$ is characteristic of the $\mathrm{C}=\mathrm{O}$ stretch of carboxylic groups [36]-[38]. The intensity of the bands of CA-2 in the region that characterizes the carboxylic groups is greater than of CA-1 sample showing a largest concentration of these compounds after acid treatment. Similar results were found in other studies of adsorption of aromatic compounds by activated carbon [39].

\subsection{Results of Adsorption Experiments}

\subsubsection{Kinetics of Adsorption}

Figure 2 show the percentage removal efficiency (ER,\%) of benzene and toluene obtained from adsorption kinetics tests. Table 3 shows the parameters of the kinetic models used to correlate the experimental data.

The removal efficiency of benzene or toluene as a function of time, after 25 minutes of contact was greater than $90.0 \%$ in all tests.

The Kolgomorov-Smirnov test, we verified the normality of the data removal efficiency (ER,\%) for the adsorption of benzene by both adsorbents. The parametric samples $t$ test showed that both adsorbents differ statistically at $5 \%$ significance level.

For the adsorption kinetics of toluene, both adsorbents showed non-normality of the data removal efficiency. The adsorbents were statistically different at the $5 \%$ significant level. 


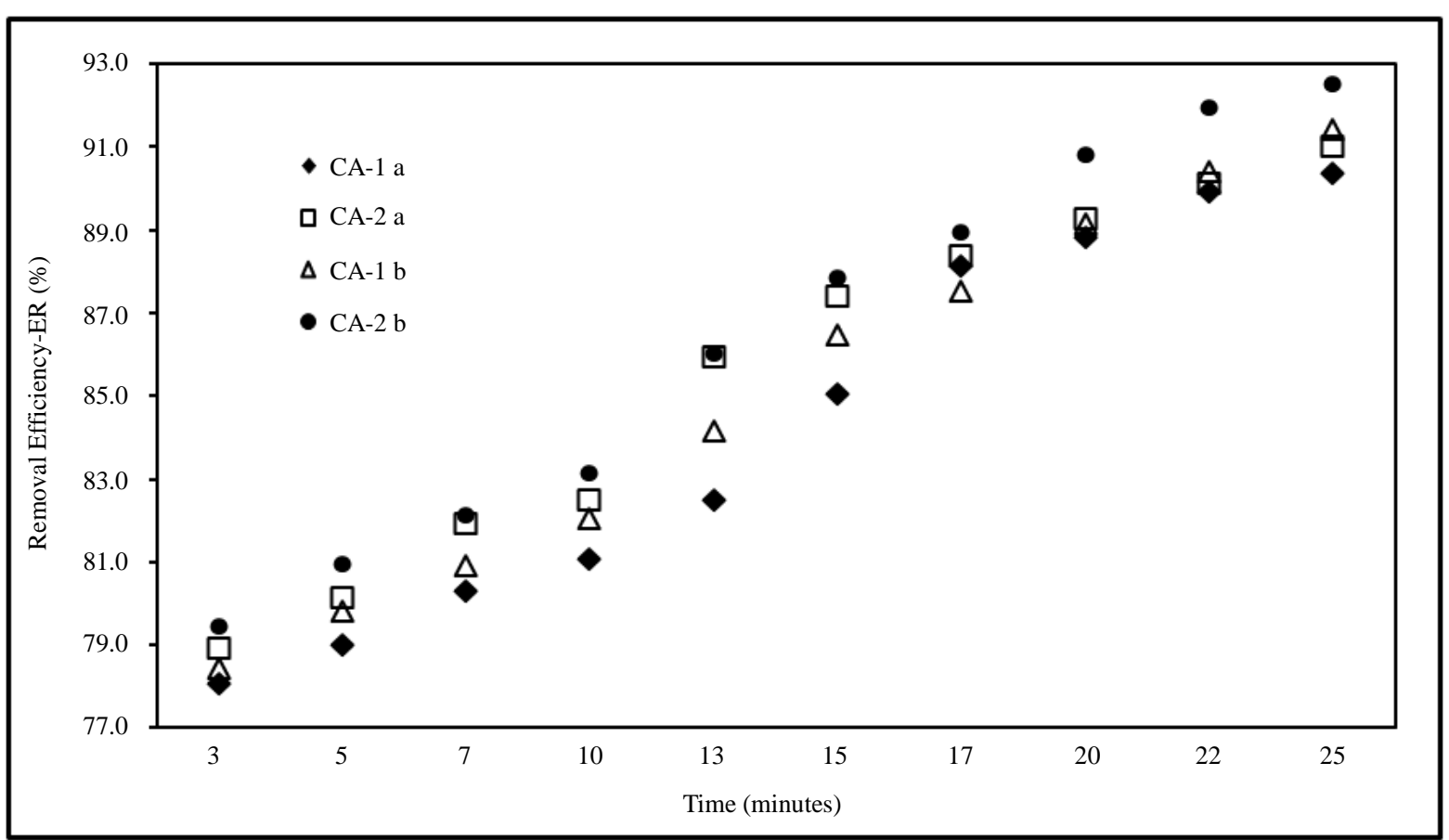

Figure 2. Removal efficiency of benzene (a) and toluene (b) by CA-1 and CA-2.

Table 3. Kinetic parameters for the removal of benzene and toluene for the CA-1 and CA-2 adsorbents.

\begin{tabular}{|c|c|c|c|c|c|}
\hline \multirow{3}{*}{ Kinetic models } & \multirow{2}{*}{ Parameter } & \multicolumn{2}{|c|}{ Benzene } & \multicolumn{2}{|c|}{ Toluene } \\
\hline & & CA-1 & CA-2 & CA-1 & CA-2 \\
\hline & $q_{e}^{\exp }(\mathrm{mg} / \mathrm{g})$ & $5.42 \pm 0.95$ & $5.47 \pm 0.8$ & $5.49 \pm 0.72$ & $5.55 \pm 0.75$ \\
\hline \multirow{6}{*}{ Pseudo-second order } & $q_{e}^{\mathrm{cal}}(\mathrm{mg} / \mathrm{g})$ & $4.81 \pm 1.3$ & $3.74 \pm 1.2$ & $5.18 \pm 1.0$ & $5.32 \pm 1.0$ \\
\hline & $k_{2}(\mathrm{~g} / \mathrm{mg} \cdot \min )$ & $0.24 \pm 0.03$ & $0.28 \pm 0.02$ & $0.21 \pm 0.01$ & $0.20 \pm 0.01$ \\
\hline & $R^{2}$ & 0.997 & 0.998 & 0.998 & 0.999 \\
\hline & $S Q E$ & 1.65 & 1.3 & 0.45 & 0.92 \\
\hline & $s$ & 0.31 & 0.31 & 0.29 & 0.29 \\
\hline & $s^{2}$ & 0.08 & 0.09 & 0.09 & 0.08 \\
\hline
\end{tabular}

\subsubsection{Adsorption Balance}

Figure 3 shows the experimental data having applied Langmuir mathematical model for the CA-1 and CA-2. Table 4 shows the parameters calculated using the model. From the results showed that the data perfectly fits the Langmuir mathematical model.

The maximum adsorbed benzene and toluene amount, according to the Langmuir model $\left(\mathrm{Q}_{\max }\right)$ was around $6.0 \mathrm{mg} / \mathrm{g}$ for the two adsorbents. $\mathrm{R}_{\mathrm{L}}$ values were within the range $\left(0<\mathrm{R}_{\mathrm{L}}<1\right)$, which according to Ho et al. [40] and Dizge et al. [41] indicate favorable adsorption type of benzene and toluene by both adsorbents. Similar results were found by Daifullah and Girgs [35] in their work on BTEX adsorption using activated carbon.

This experimental data one show that there is no significant difference in the adsorption of benzene and toluene using these adsorbents.

\subsubsection{Adsorption in Fixed Bed}

Figure 4 and Figure 5 show the rupture curves for the adsorption of benzene and toluene (Figure 5) at the optimum volumetric flow rate $(70 \mathrm{ml} / \mathrm{min})$ using CA-2. 


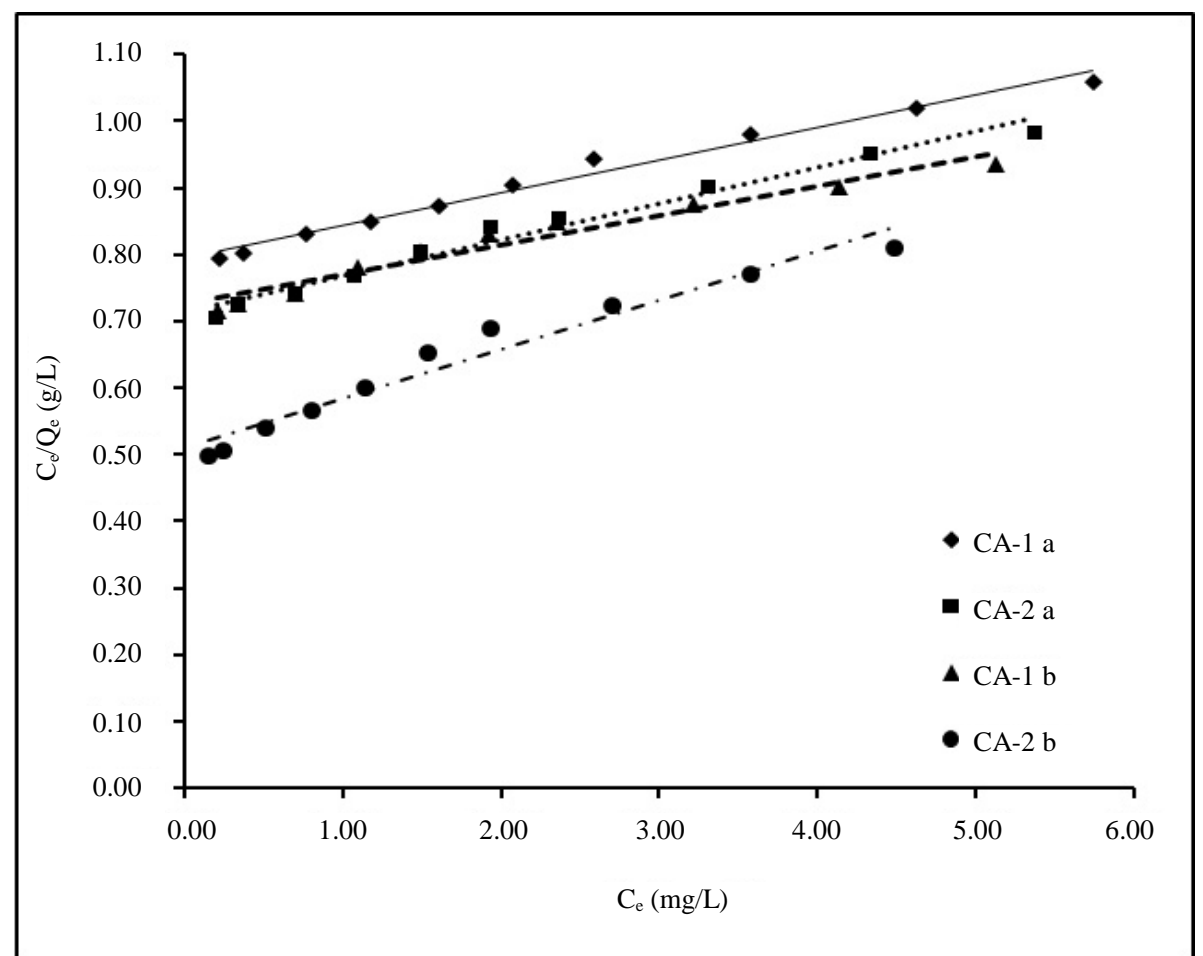

Figure 3. Data adsorption of benzene (a) and toluene (b) adjusted by Langmuir model.

Table 4. Linearised langmuir parameters for the adsorption of benzene (a) and toluene (b) CA-1 and CA-2.

\begin{tabular}{ccccc}
\hline Model & \multicolumn{4}{c}{ Langmuir } \\
\hline Adsorbents & CA-1(a) & CA-2(a) & CA-1(b) & CA-2(b) \\
\hline Parameters & & & $16.31 \pm 1.83$ & $18.42 \pm 1.20$ \\
\hline$k_{L}(L / m g)$ & $20.36 \pm 2.51$ & $22.47 \pm 2.21$ & $5.89 \pm 0.01$ & $5.99 \pm 0.02$ \\
$Q_{0}(m g / g)$ & $5.72 \pm 0.06$ & $5.73 \pm 0.04$ & 0.420 & 0.338 \\
$R_{L}$ & 0.443 & 0.416 & 0.987 & 0.989 \\
$R^{2}$ & 0.986 & 0.987 & 0.937 & 0.955 \\
$S Q E$ & 0.898 & 0.912 & 0.326 & 0.328 \\
$S$ & 0.316 & 0.318 & 0.104 & 0.106 \\
\hline$s^{2}$ & 0.099 & 0.101 & & \\
\hline
\end{tabular}

The breakpoints were around $\mathrm{c}_{\mathrm{e}} / \mathrm{c}_{0}$ values of 0.076 and 0.079 for benzene and toluene respectively, in 10 minutes. The organic percentage were around $92 \%$ for both adsorbents. The residual concentration of benzene and toluene were 4.7 and $4.5 \mathrm{mg} / \mathrm{L}$ respectively, higher than the maximum values allowed by Brazilian legislation for these organic compounds (0.05 and $0.17 \mathrm{mg} / \mathrm{L})$ [42].

Considering the experimental conditions used in this work (bed height, particle size of the adsorbent, the column internal diameter and volumetric flow rates of feeding) were not sufficiently adequate for the complete removal of benzene and toluene from aqueous effluents. The process become more efficient, if the inside diameter and the height of the bed is lower [34]. Under such conditions the losses by volatilization of organic compounds are lower. 


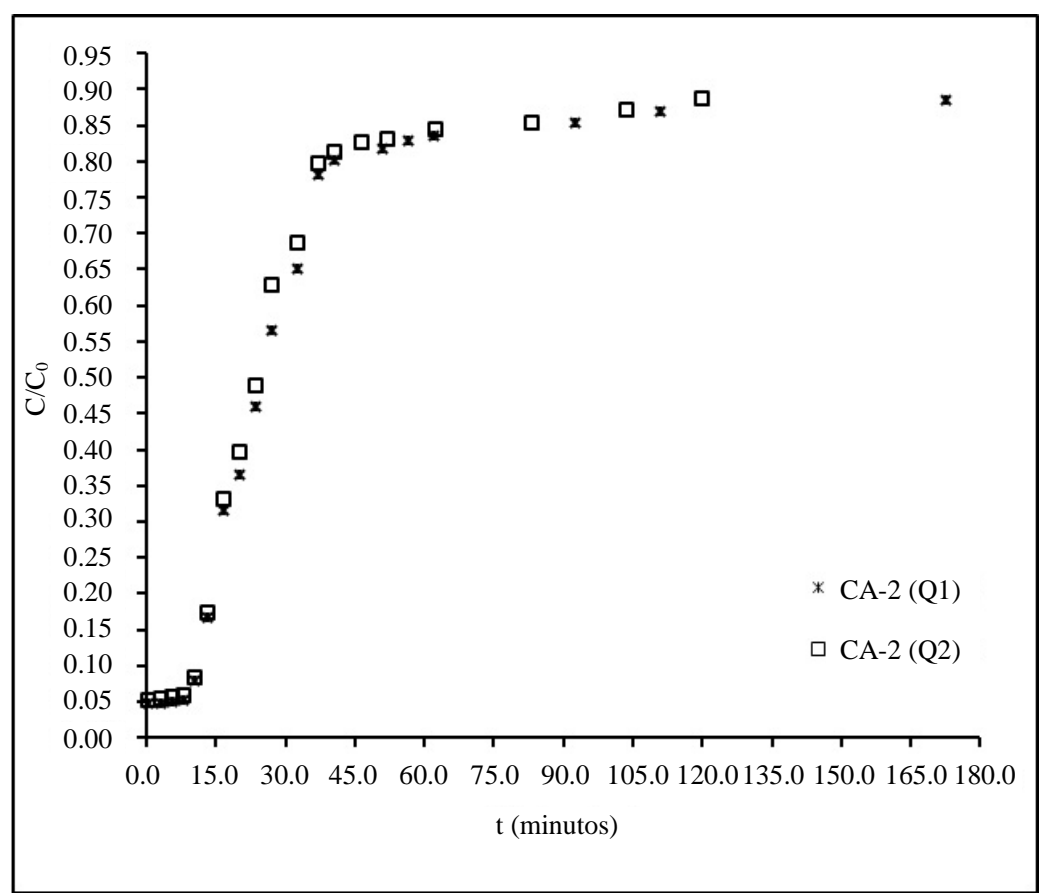

Figure 4. Rupture curve for the adsorption of benzene.

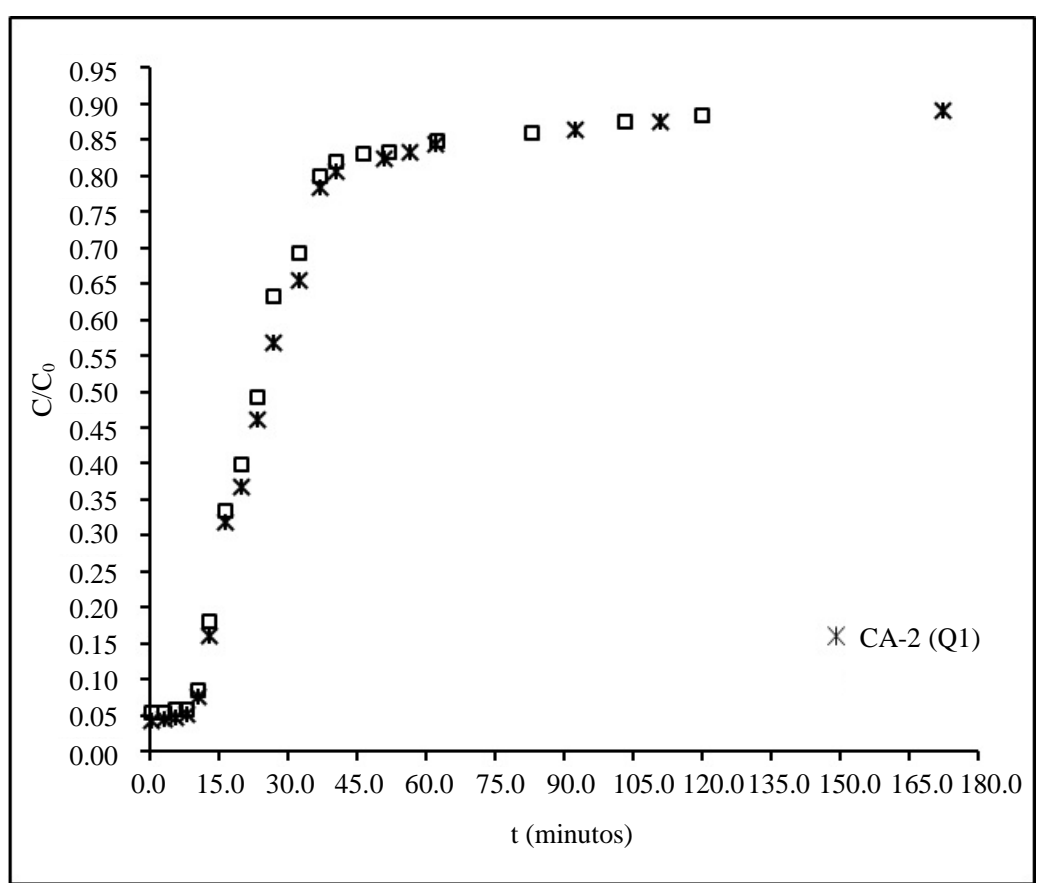

Figure 5. Rupture curve for the adsorption of toluene.

\section{Conclusions}

The treatment of commercial charcoal by $\mathrm{HNO}_{3}$ was effective because there was an increase in the concentration of surface acid groups, particularly carboxyl groups.

However, based on the experimental data one can say that there was no significant quantitative difference in the adsorption of benzene and toluene from the activated carbon treated (ca-2) in relation to in nature (ca-1). Having necessity for further studies to optimize experimental conditions of adsorption experiments, as well as 
adsorbents which can remove more efficiently organic compounds (BTEX) from industrial wastewater, surface water and groundwater in order to minimize the toxic effects of these pollutants to the environment and communities affected by them.

\section{Acknowledgements}

Graduate Program in Chemical Engineering from the Federal University of Pará (UFPA-PPEQ); Capes-CNPq; Laboratory of Toxicology—Environment Section—InstitutoEvandroChagas/Para/Brazil.

\section{References}

[1] Arambarri, I., Lasa, M., Garcia, R. and Millan, E. (2004) Determination of Fuel Dialkyl Ethers and BTEX in Water Using Headspace Solid-Phase Microextraction and Gas Chromatography-Flame Ionization Detection. Journal of Chromatography A, 1033, 193-203. http://dx.doi.org/10.1016/j.chroma.2004.01.046

[2] Roldan, P.S., Alcantara, I.L., Castro, G.R., Rocha, J.C., Padilha, C.C.F. and Padilha, P.M. (2003) Determination Heavy Metals and Organic Compounds in Fuel Ethanol by FAAS after Enrichment in Column Packed with 2-AminothiazoleModified Silica Gel. Analytical Chemical, 375, 574-577.

[3] Su, F., Lu, C. and Hu, S. (2010) Adsorption of Benzene, Toluene, Ethylbenzene and p-Xylene by NaOCl-Oxidized Carbon Nanotubes. Colloids and Surface A, 353, 83-91. http://dx.doi.org/10.1016/j.colsurfa.2009.10.025

[4] Benkhedda, E.A. (2000) Experimental and Modeled Results Describing the Adsorption of Toluene onto Activated Carbon. Journal of Chemical Engineering Data, 45, 650-653. http://dx.doi.org/10.1021/je000010f

[5] Lillo-Ródenas, M.A., Fletcher, A.J., Thomas, K.M., Cazorla-Amorós, D. and Linares-Solano, A. (2006) Competitive Adsorption of a Benzene-Toluene Mixture on Activated Carbons at Low Concentration. Carbon, 44, 1455-1463. http://dx.doi.org/10.1016/j.carbon.2005.12.001

[6] Chingombe, P., Saha, B. and Wakeman, R.J. (2005) Surface Modification and Characterisation of a Coal-Based Activated Carbon. Carbon, 43, 3132-3143. http://dx.doi.org/10.1016/j.carbon.2005.06.021

[7] Monser, L. and Adhoum, N. (2002) Modified Activated Carbon for the Removal of Copper, Zinc, Chromium and Cyanide from Wastewater. Separation and Purification Technology, 26, 137-146. http://dx.doi.org/10.1016/S1383-5866(01)00155-1

[8] Lillo-Ródenas, M.A., Cazorla-Amorós, D. and Linares-Solano, A. (2005) Behaviour of Activated Carbons with Different Pore Size Distributions and Surface Oxygen Groups for Benzene and Toluene Adsorption at Low Concentrations. Carbon, 43, 1758-1767. http://dx.doi.org/10.1016/j.carbon.2005.02.023

[9] Derbyshire, F., Jagtoyen, M., Andrews, R., Rao, A., Martin-Gullon, I. and Grulke, E.A. (2000) Carbon Materials in Environmental Applications. Carbon Materials in Environmental Applications, 27, 1-66.

[10] Wibowo, N., Setyadhi, L., Wibowo, D., Setiawan, J. and Ismadji, S. (2007) Adsorption of Benzene and Toluene from Aqueous Solutions onto Activated Carbon and Its Acid and Heat Treated Forms: Influence of Surface Chemistry on Adsorption. Journal of Hazardous Materials, 146, 237-242. http://dx.doi.org/10.1016/j.jhazmat.2006.12.011

[11] Moreno-Castilla, C. (2004) Adsorption of Organic Molecules from Aqueous Solutions on Carbon Materials. Carbon, 42, 83-94. http://dx.doi.org/10.1016/j.carbon.2003.09.022

[12] Yang, R.T. (2003) Adsorbents: Fundamentals and Applications. John Wiley \& Sons Inc., Hoboken. http://dx.doi.org/10.1002/047144409X

[13] Nagano, S., Tamon, H., Adzumi, T., Nakagawa, K. and Suzuki, T. (2000) Activated Carbon from Municipal Waste. Carbon, 38, 915-920. http://dx.doi.org/10.1016/S0008-6223(99)00208-0

[14] Juang, R., Wu, F. and Tseng, R. (2002) Characterization and Use of Activated Carbons Prepared from Bagasses for Liquid-Phase Adsorption. Colloids and Surfaces A, 201, 191-199. http://dx.doi.org/10.1016/S0927-7757(01)01004-4

[15] Yin, C.Y., Aroua, M.K. and Daud, W.M.A.W. (2007) Review of Modifications of Activated Carbon for Enhancing Contaminant Uptakes from Aqueous Solutions. Separation and Purification Technology, 52, 403-415. http://dx.doi.org/10.1016/j.seppur.2006.06.009

[16] El-Hendawy, A.A. (2003) Influence of $\mathrm{HNO}_{3}$ Oxidation on the Structure and Adsorptive Properties of Corncob-Based Activated Carbon. Carbon, 41, 713-722. http://dx.doi.org/10.1016/S0008-6223(03)00029-0

[17] American Society for Testing and Materials (2005) Standard Test Method for pH of Activated Carbon Method: ASTM D 3838. American Society for Testing and Materials, Pennsylvania.

[18] Youssef, A.M., El-Nabarawy, T. and Samra, S.E. (2004) Sorption Properties of Chemically-Activated Carbons: 1. Sorption of Cadmium(II) Ions. Colloids and Surfaces A, 235, 153-163. http://dx.doi.org/10.1016/j.colsurfa.2003.12.017

[19] Boehm, H.P. (1994) Some Aspects of the Surface Chemistry of Carbon Blacks and Other Carbons. Carbon, 32, 759- 
769. http://dx.doi.org/10.1016/0008-6223(94)90031-0

[20] Bueno, C.I.C. and Carvalho, W.A. (2007) Lead(II) Removal in Discontinous Systems by Carbon Activated by Phosphoric Acid and Vapor. Química Nova, 30, 1911-1918. http://dx.doi.org/10.1590/S0100-40422007000800022

[21] Lu, C., Su, F. and Hu, S. (2008) Surface Modification of Carbon Nanotubes for Enchancing BTEX Adsorption from Aqueous Solutions. Applied Surface Science, 254, 7035-7041. http://dx.doi.org/10.1016/j.apsusc.2008.05.282

[22] Stenerson, K.M. and Wallace, R.F. (2008) Método 6040 D-Odors in Drinking Water, Using SPME on the Supelco SLB-5ms Capillary Column-SUPELCO ${ }^{\circledR}$ Analytical. LG-GC Solutions for Separations Scientists. http://www.chromatographyonline.com/node/231813?rel=canonical

[23] Method 0010-Method for Determining Polynuclear Aromatic Hydrocarbons (PAHS) in Stack Gas-Emissions Assessment of Conventional Stationary Combustion Systems: Methods and Procedure Manual for Sampling and Analysis. ${ }^{\circ}$ 2009, Test America Laboratories, Inc., All rights reserved Test America \& Desing ${ }^{\mathrm{TM}}$ are trademarks of Test America Laboratories, Inc. http://www.epa.gov/osw/hazard/testmethods/sw846/pdfs/0010.pdf

[24] Villacanas, F., Pereira, M.F.R., Orfao, J.J.M. and Figueiredo, J.L. (2006) Adsorption of Simple Aromatic Compounds on Activated Carbons. Journal of Colloid and Interface Science, 293, 128-136. http://dx.doi.org/10.1016/j.jcis.2005.06.032

[25] Castilla, M.C. (2004) Eliminacion de Contaminantes Orgânicos de las águas mediante adsorción em materiales de carbón. Departamento de Quimica Inorgánica, Facultad de Ciencias, Espanha. https://www.uam.es/ss/Satellite/Ciencias/es/1242669602003/contenidoFinal/Departamento_de_Quimica_Inorganica.html

[26] Streat, M., Patrick, J.W. and Perez, M.J.C. (1995) Sorption of Phenol and Para-Chlorophenol from Water Using Conventional and Novel Activated Carbons. Water Research, 29, 467-472. http://dx.doi.org/10.1016/0043-1354(94)00187-C

[27] Ruthven, D.M. (1984) Principles of Adsorption. John Wiley \& Sons, Hoboken.

[28] Mangun, C.L., Yue, Z. and Economy, J. (2002) Adsorption of Organic Contaminants from Water Using Tailored ACFs. Chemistry of Materials, 13, 2356-2360. http://dx.doi.org/10.1021/cm000880g

[29] Ania, C.O., Parra, J.B. and Pis, J.J. (2002) Effect of Texture and Surface Chemistry on Adsorptive Capacities of Activated Carbons for Phenolic Compounds Removal. Fuel Processing Technology, 77-78, 337-343. http://dx.doi.org/10.1016/S0378-3820(02)00072-3

[30] Marato-Valer, M.M., Dranca, I., Lupascu, T. and Nastas, R. (2004) Effect of Adsorbate Polarity on Thermodesorption Profiles from Oxidized and Metal-Impregnated Activated Carbons. Carbon, 42, 2655-2659. http://dx.doi.org/10.1016/j.carbon.2004.06.007

[31] Rios, R.V.A., Alves, D.E., Dalmazio, I., Bento, S.F.V., Donnici, C.L. and Lago, R.M. (2003) Tailoring Activated Carbon by Surface Chemical Modification with O, S, and N Containing Molecules. Materials Research, 6, 129-135. http://dx.doi.org/10.1590/S1516-14392003000200004

[32] Aburub, A. and Wurster, D.E. (2006) Phenobarbital Interactions with Derivatized Activated Carbon Surfaces. Journal of Colloid and Interface Science, 296, 79-85. http://dx.doi.org/10.1016/j.jcis.2005.08.035

[33] Julien, F., Baudu, M. and Mazet, M. (1998) Relationship between Chemical and Physical Surface Properties of Activated Carbon. Water Research, 32, 3414-3424. http://dx.doi.org/10.1016/S0043-1354(98)00109-2

[34] Jankowska, H. and Swiatkowski, A. (1991) Active Carbon, Chapter 3: Structure and Chemical Nature of Surface, 106-107. Ellis Horwood Series in Physical Chemistry.

https://books.google.com.br/books?id=m81QAAAAYAAJ\&q=Jankowska,+H.,+Swiatkowski, +A., +and+Choma, + J.\&d q=Jankowska, + H., + Swiatkowski, + A., + and+Choma, + J.\&hl=pt-BR\&sa=X\&ei=1LZHVZaeFcnFggSoiIDQBA\&ved=0C C4Q6AEwAg

[35] Daifullah, A.A.M. and Girgis, B.S. (2003) Impact of Surface Characteristics of Activated Carbon on Adsorption of BTEX. Colloids and Surfaces A, 214, 181-193. http://dx.doi.org/10.1016/S0927-7757(02)00392-8

[36] Figueiredo, J.L., Pereira, M.F.R., Freitas, M.M.A. and Órfão, J.J.M. (1999) Modification of the Surface Chemistry of Activated Carbons. Carbon, 37, 1379-1389. http://dx.doi.org/10.1016/S0008-6223(98)00333-9

[37] Ahmedna, M., Marshall, W.E. and Rao, R.M. (2000) Surface Properties of Granular Activated Carbons from Agricultural By-Products and Their Effects on Raw Sugar Decolorization. Bioresource Technology, 71, 103-112. http://dx.doi.org/10.1016/S0960-8524(99)90069-X

[38] Tomaszewski, W., Gun’ko, V.M., Zieba, J.S. and Leboda, R. (2003) Structural Characteristics of Modified Activated Carbons and Adsorption of Explosives. Journal of Colloid and Interface Science, 266, 388-402. http://dx.doi.org/10.1016/S0021-9797(03)00633-7

[39] Anirudhan, T.S., Sreekumari, S.S. and Bringle, C.D. (2009) Removal of Phenols from Water and Petroleum Industry Refinery Effluents by Activated Carbon Obtained from Coconut Coir Pith. Adsorption, 15, 439-451. http://dx.doi.org/10.1007/s10450-009-9193-6 
[40] Ho, Y.S. and Mckay, G. (1999) Pseudo-Second Order Model for Sorption Processes. Process Biochemistry, 34, 451465. http://dx.doi.org/10.1016/S0032-9592(98)00112-5

[41] Dizge, N., Aydiner, C., Demirbas, E., Kobya, M. and Kara, S. (2008) Adsorption of Reactive Dyes from Aqueous Solutions by Fly Ash: Kinetic and Equilibrium Studies. Journal of Hazardous Materials, 150, 737-746. http://dx.doi.org/10.1016/j.jhazmat.2007.05.027

[42] Padilha, A.R.S. (2011) Portarian 2914, de 12 de dezembro de 2011-Ministério da Saúde. http://177.153.6.85/portaria2914/theme/documentos/002.pdf 